\title{
Flora of Espírito Santo, Brazil Flora of Espírito Santo: Capparaceae
}

\author{
Jaquelini Luber ${ }^{1,2,5}$, Tatiana Tavares Carrijo ${ }^{3} \&$ Vidal de Freitas Mansano ${ }^{2,4}$
}

\begin{abstract}
Capparaceae is a pantropical family of Angiosperm with about 40 to 45 genera and 700 to 900 species, which presents a wide morphological variation in flowers and fruits. There are 12 genera and 30 species of the family in Brazil, a half of it occurring in the Atlantic Forest. Here we study the species of Capparaceae occurring in Espírito Santo, with the objective of expanding the knowledge about the richness of this family in Atlantic Forest. The study was based on the analysis on herbaria collections, as well as samples collected during field collections. Capparaceae in Espírito Santo state is represented by the genera Capparidastrum (1 sp.), Crateva (1 sp.), Cynophalla (2 spp.), Mesocapparis (1 sp.), Monilicarpa (1 sp.) and Neocalyptrocalyx (2 spp.). Cynophalla grandiflora is first described here. Capparaceae is commonly found at a maximum altitude of $600 \mathrm{~m}$ in Espírito Santo, predominantly in "tabuleiros costeiros" and coastal plains, without records in mountainous regions. Morphological characteristics of such as habitat, pubescence, tertiary veins, nectaries on leaf axils and type of fruit, are fundamental for the delimitation of the species.
\end{abstract}

Key words: Cynophalla, new species, tertiary veins.

\section{Resumo}

Capparaceae é uma família pantropical de Angiosperma com cerca de 40 a 45 gêneros e 700 a 900 espécies, as quais apresentam uma ampla variação morfológica nas flores e frutos. No Brasil, ocorrem 12 gêneros e 30 espécies, sendo que a metade ocorre na Floresta Atlântica. As espécies que ocorrem no Espírito Santo foram estudadas, com o objetivo de ampliar o conhecimento sobre a riqueza e a diversidade da família na Floresta Atlântica. O estudo baseou-se na análise de coleções de herbários, bem como em amostras coletadas em expedições de campo. Capparaceae no estado do Espírito Santo é representada pelos gêneros Capparidastrum (1 sp.), Crateva (1 sp.), Cynophalla (2 spp.), Mesocapparis (1 sp.), Monilicarpa (1 sp.) e Neocalyptrocalyx (2 spp.). Cynophalla grandiflora é descrita aqui pela primeira vez. Capparaceae é comumente encontrada em uma altitude máxima de $600 \mathrm{~m}$ no Espírito Santo, predominantemente em planícies costeiras e tabuleiros costeiros, sem registros em regiões montanhosas. As características morfológicas como habitat, pubescência, nervuras terciárias, nectários na axila das folhas e tipo de fruto, foram fundamentais para a delimitação das espécies.

Palavras-chave: Cynophalla, espécie nova, nervura terciária.

\section{Introduction}

The family Capparaceae has a wide morphological diversity, mainly observed in the flower and fruit (Mabberley 1997). The flowers can be actinomorphic or zygomorphic and the number of stamens can vary from one to more than 250 (Endress 1992). The protruding base of the flowers is interspersed with an elongated area

\footnotetext{
${ }^{1}$ Instituto de Pesquisas Jardim Botânico do Rio de Janeiro, Escola Nacional de Botânica Tropical, Prog. Pós-graduação em Botânica, Jardim Botânico, Rio de Janeiro, RJ, Brazil. ORCID: <https://orcid.org/0000-0002-6662-1710>.

${ }^{2}$ Instituto de Pesquisas Jardim Botânico do Rio de Janeiro, DIPEQ, Jardim Botânico, Rio de Janeiro, RJ, Brazil.

${ }^{3}$ Universidade Federal do Espírito Santo, Centro de Ciências Exatas, Naturais e da Saúde, Depto. Biologia, Lab. Botânica, Alto Universitário, Guararema, Alegre, ES, Brazil. ORCID: <https://orcid.org/0000-0002-8366-0738>.

${ }^{4}$ ORCID: < https://orcid.org/0000-0002-7204-0744>.

${ }^{5}$ Author for correspondence: luber.bio@gmail.com
} 
that produces gynophores, androgynophores, and elongated stamens (Endress 1992). The fruits can be classified as amphisarca, capsules or pepos, with variations in shape, color, consistency, and dehiscence.

Described in 1789 by Jussieu in the Genera Plantarum, Capparaceae was represented by 12 genera. Since then, several new species and genera have been described in the family, amounting to about 40 to 45 genera and approximately 700 to 900 species distributed throughout the Pantropical region (Cronquist 1981; Heywood 1993). Neotropical species, in particular, have undergone several reorganizations as to their taxonomic position, mainly in the genus Capparis sensu lato, which currently does not occur in the Neotropics. This reorganization and novel taxonomic information have led to the description of new species and genera (Iltis \& Cornejo 2007; Cornejo \& Iltis 2008a, b, c, 2009a, b, 2010; Cornejo et al. 2014, 2020; Cornejo 2020; Cornejo \& Vargas 2020; Mercado-Gómez \& Morales-Puentes 2020), substantially increasing the richness and diversity of Capparaceae in the neotropical region to18 genera and 110 species (Cornejo \& Iltis 2010, 2012).

Twelve genera and 30 species occur in Brazil, and 11 species are endemic (Soares Neto $\&$ Luber 2020). Flora surveys have been carried out mainly in the Atlantic Forest and Caatinga biomes, in the states of Rio de Janeiro (Carvalho 1959), Pernambuco (Costa e Silva 1995), Ceará (Soares Neto et al. 2014), and Rio Grande do Norte (Soares Neto \& Jardim 2015). A large part of the richness is recorded in Atlantic Forest biome, with records of nine genera and 15 species, four of which are endemic (Soares Neto \& Luber 2020).

The project "Flora of Espírito Santo", to which the present work is linked, seeks to fill the lack of studies on the richness and diversity of species for the state of Espírito Santo. Thus, herein a study of Capparaceae is provided, expanding the knowledge about the taxonomy, morphology, geographic distribution, and species richness of the family, and presenting an identification key, morphological descriptions, distribution maps, and illustrations. The present work also expands the knowledge about the richness of the family through the description of Cynophalla grandiflora Luber, a new species to science.

\section{Material and Methods}

Study area

The state of Espírito Santo (ES) is located in the Southeast of Brazil between the parallels $17^{\circ} 53^{\prime} 29^{\prime \prime} \mathrm{S}$ and $21^{\circ} 18^{\prime} 03^{\prime \prime} \mathrm{S}$, and the meridians $39^{\circ} 41^{\prime} 18^{\prime \prime} \mathrm{W}$ and $41^{\circ} 52^{\prime} 45^{\prime \prime} \mathrm{W}$, bordered by the state of Bahia to the north, Minas Gerais to the west, Rio de Janeiro to the south, and limited by the Atlantic Ocean to the east. Three geomorphological regions are recognized in the state (IPEMA 2005): the mountainous region (characterized by crystalline Precambrian rocks and altitudes that reach 2,897 m); "tabuleiros costeiros" (formed by quaternary continental sediments at altitudes that reach no more than $100 \mathrm{~m}$ ); and coastal plains (formed by quaternary sediments at altitudes that do not exceed $15 \mathrm{~m}$ ).

\section{Taxonomic treatment}

The work was developed based on the analysis of collections deposited in herbaria and fieldwork. Morphological analyses were made on exsiccates from the herbaria CAP, CVRD, MBML, RB, SAMES, and VIES (acronyms according to Thiers, continuously updated), which have the best botanical collections for Espírito Santo. Additional materials from other states and other herbaria (CEPEC, INPA, MAC, and US) were used to complement the descriptions of the species. The identification was based on specialized bibliography for Capparaceae (Cornejo \& Iltis 2008a; Soares Neto et al. 2014; Soares Neto \& Jardim 2015). Online digitized material, including type material (CRIA 2015; Reflora 2015; and Global Plants 2020), were also consulted.

The fieldwork consisted of expeditions carried out between January 2018 and September 2020, covering the entire state of Espírito Santo and its different phytophysiognomies (IPEMA 2005). Information on morphological aspects of the species and characteristics of the environment were observed and registered in the field, and a photographic record and GPS coordinates were obtained.

\section{Morphological descriptions}

Morphological descriptions were made based on measurements taken in herborized material, always in the middle part of fully developed structures. The concepts and terminologies used in the descriptions follow Gonçalves \& Lorenzi (2007). The dichotomous identification key sought 
to use, in addition to reproductive characters, vegetative characters that are easy to observe.

The range geographic of distribution of the species was mapped using the Quantum-GIS program based on coordinates of the localities where each species were recorded or coordinates taken in the field. When notes on coordinates were not available, the reference point for the city of collection was used.

\section{Results and Discussion}

Eight species of Capparaceae belonging to six different genera were registered for Espírito Santo. Amongst the species, there is Cynophalla grandipetala Luber, described as new to science, found in vegetation of "tabuleiros costeiro".
The wide morphological variation and the low number of collections of Capparaceae are among the greatest difficulties in understanding the morphological limits between closely related species. However, recent morphological studies discuss in more detail the morphology of this family and contribute to ameliorate such difficulties (Cornejo \& Iltis 2008a; Soares Neto et al. 2014; Soares Neto \& Jardim 2015; Cornejo et al. 2020).

Capparaceae is a family that occurs mainly at low altitudes (Cardinal-McTeague et al. 2016). In Espírito Santo, the species were found at a maximum altitude of $600 \mathrm{~m}$, thus absent in regions characterized as mountainous, and were mainly distributed on "tabuleiros costeiros" and coastal plains (Figs. 1-2).

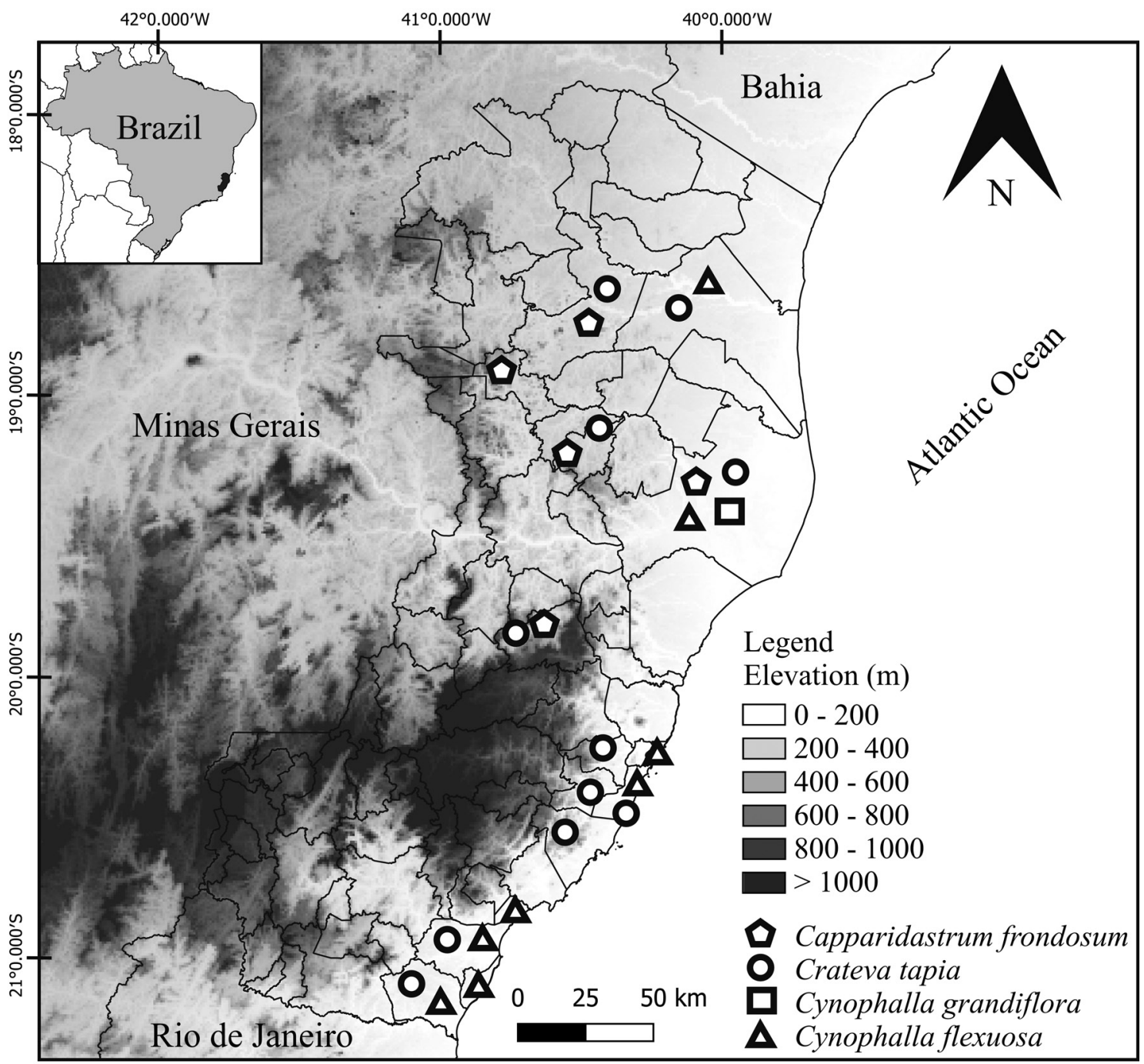

Figure 1 - Distribution of Capparaceae species in Espírito Santo, with elevation data. 
Taxonomic treatment

Capparaceae Juss. Genera Plantarum 242. 1789.

Tree, shrub, or herbaceous or woody liana (Mesocapparis). Leaves simple or 3-foliolate (Crateva), alternate, distichally or spirally arranged, congested at the apex of the branch; nectaries on the leaf axil present (Cynophalla) or absent; blade membranaceous to coriaceous, glabrous or pubescent, when pubescent with stellate trichomes; veins abaxially and adaxially impressed or prominent, tertiary veins varying from prominent and very reticulate to impressed and little reticulate or not visible. Inflorescences solitary or racemose, corymbose, or paniculate, terminal or axillary. Flowers symmetrical or asymmetrical (Crateva); nectaries at the internal base of the sepals present or absent (Monilicarpa); calyx open at anthesis or in the form of a calyptra (Neocalyptrocalyx); sepals heteromorphic or homomorphic; petals 4, white, light-pink or lightyelow, unguiculate (Crateva) or not, reflexed at anthesis or not; stamens 17-100; filaments completely white or white and purple; anthers basifixed or dorsifixed; gynophore glabrous or partially to completely pubescent, costate or not; stigma capitate; ovary glabrous or pubescent, differentiated from the gynophore or not. Fruits follicular capsule, moniliform capsule, or elliptical or globose amphisarca, dehiscent or indehiscent, green, yellow, lilac or red.

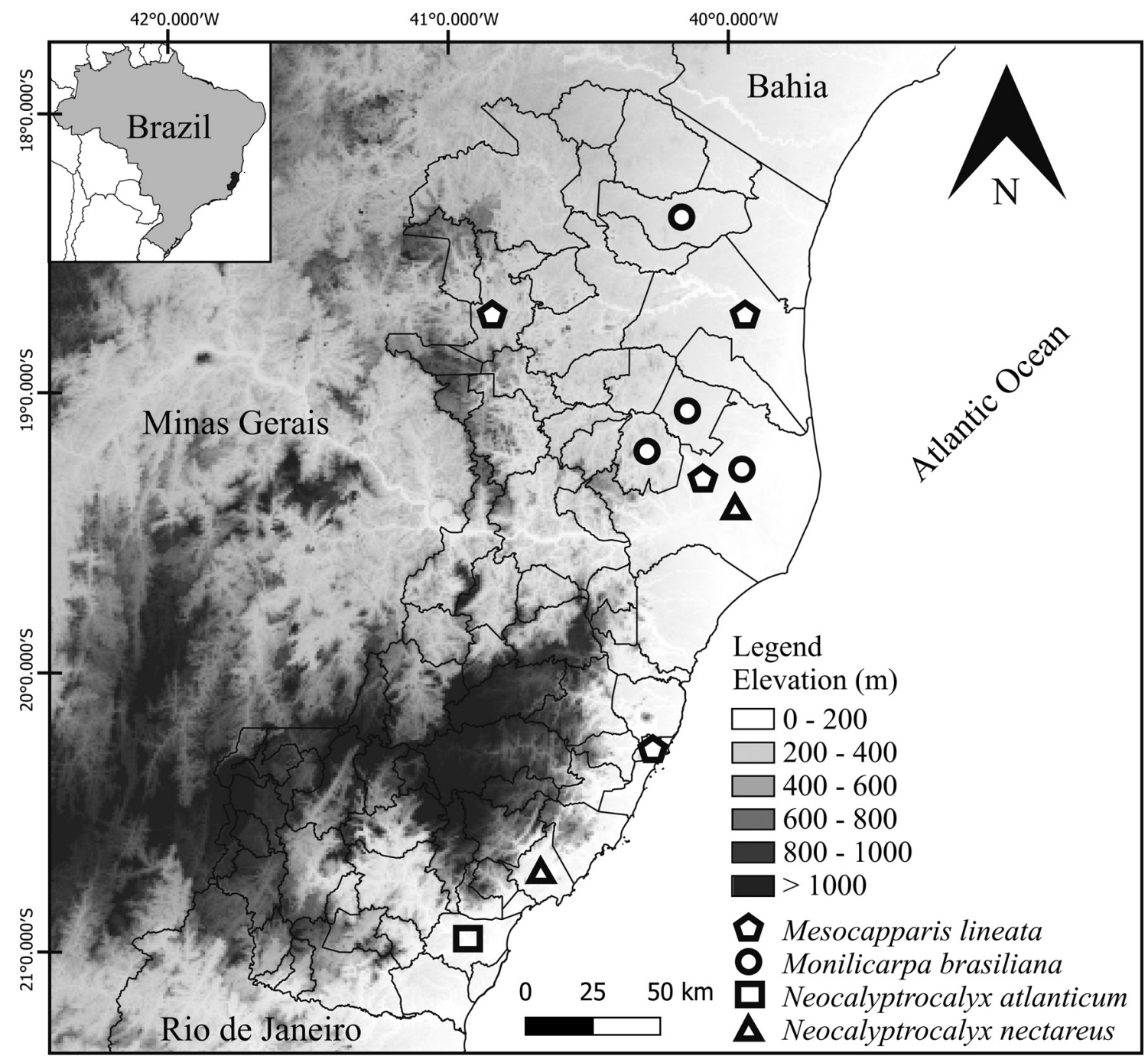

Figure 2 - Distribution of Capparaceae species in Espírito Santo, with elevation data. 


\section{Identification key for Capparaceae in Espírito Santo}

1. Leaf 3-foliolate, flowers asymmetrical, petals unguiculate 2.1. Crateva tapia

1'. Leaf simple, flowers symmetrical, petals not unguiculate 2

2. Sepals homomorphic

3. Herbaceous or woody lianas, leaf blade tomentose on the abaxial face and pubescent on the adaxial face, fruit globose amphisarca. 4.1. Mesocapparis lineata

3'. Trees or shrubs, leaf blade glabrous, fruit capsule 4

4. Inflorescence with more than 26 flowers, bracts narrow-elliptical, 2-3 mm long, petals not reflexed at anthesis, filaments completely white. 5.1. Monilicarpa brasiliana

4'. Inflorescence with less than 26 flowers, bracts deltoid, $1 \mathrm{~mm}$ long, petals reflexed at anthesis, filaments purple at the base and white at the apex

1.1. Capparidastrum frondosum

2'. Sepals heteromorphic

5. Leaf blade pubescent with stellate trichomes, nectaries on the leaf axil absent

6 (Neocalyptrocalyx)

6. Leaf blade elliptical, apex attenuate, flower buds apex thinly apiculate to broadly obtuse, $12-20 \times 15 \mathrm{~mm}$, petals light-pink, filaments $10-22 \mathrm{~mm}$ long, gynophore $3.5 \mathrm{~mm}$ long, ovary $3 \mathrm{~mm}$ long..... 6.1. Neocalyptrocalyx atlanticum

6'. Leaf blade lanceolate to elliptic-lanceolate, apex sharply acuminate, flower buds apex acuminate, 9-12 × 7-9 mm, petals white, filaments 23-33 mm long, gynophore 11-19 $\mathrm{mm}$ long, ovary $5.3-6.5 \mathrm{~mm}$ long....

6.2. Neocalyptrocalyx nectarius

5'. Leaf blade glabrous, nectary on the leaf axil present. .7 (Cynophalla)

7. Leaf blade membranaceous with tertiary veins impressed and slightly reticulate on both sides and slightly reticulate tertiary veins, external sepals $8-10 \times 7-10 \mathrm{~mm}$, internal sepals $14 \times 12-13 \mathrm{~mm}$, petals $20-30 \times 18-22 \mathrm{~mm}$, ovary not differentiated from gynophore.

3.2. Cynophalla grandiflora

7'. Leaf blade coriaceous with tertiary veins abaxially prominent and adaxially prominent or impressed, densely reticulate, external sepals $5-7 \times 6-8 \mathrm{~mm}$, internal sepals $7 \times 4-10$ $\mathrm{mm}$, petals $12-18 \times 8-10 \mathrm{~mm}$, ovary differentiated from gynophore

3.1. Cynophalla flexuosa

1.1. Capparidastrum frondosum (Jacq.) Cornejo \& Iltis, Harvard Papers in Botany 13(2): 232-233. 2008.

Figs. 3a-c; 4a

Tree or shrub 1-7 m tall. Leaves alternate spiral, congested at the apex of the branch, simple, petioles $6-11 \mathrm{~mm}$ long, cylindrical to slightly canaliculate, glabrous; nectary on the leaf axil absent; blade 17-26.3 × 5-8.4 cm, glabrous on both sides, chartaceous, oblanceolate to elliptical, apex attenuate to obtuse, base obtuse, subcordate or cuneate; veins abaxially prominent and adaxially impressed, 10-13 pairs, tertiary veins impressed and little reticulate on both sides. Inflorescences a corymb, terminal. Flowers symmetrical, 7-12 per inflorescence, inflorescence axis 40-105 mm long; bracts $1 \mathrm{~mm}$ long, glabrous, chartaceous, deltoid; pedicel 14-27 mm long, glabrous; floral buds $10-14 \times 9-11 \mathrm{~mm} ; 4$ nectaries; calyx open at anthesis; sepals homomorphic, $1.5-2 \times 2 \mathrm{~mm}$, membranaceous, deltoid, glabrous, green; petals $4,11-12 \times 7-8 \mathrm{~mm}$, elliptical, margin entire, membranaceous, glabrous, white, reflexed at anthesis; stamens 30-50; filaments 24-28 mm long, glabrous, purple at the base and white at the apex, 5 lines of insertion; anthers $2-2.5 \mathrm{~mm}$ long, dorsifixed, ovate; gynophore, $8-9 \mathrm{~mm}$ long, glabrous, not fenestrated; stigma capitate, black when dry; ovary 4-5.5 mm long, glabrous, differentiated from the gynophore. Fruits follicular capsule, indehiscent, lilac, $4-5.2 \times 0.7-1 \mathrm{~cm}$; peduncle 10-12 × 1-2 mm; developed gynophore $11-14 \times 1-1.5 \mathrm{~mm}$.

Specimens studied: Águia Branca, 5.IX.2006, fl., L.F.S. Magnago et al. 1273 (MBML). Governador Lindemberg, 5.XI.2007, fl., V. Demuner 4444 (MBML). Linhares, 18.X.1995, fl., D.A. Folli 2663 (CVRD). Marilândia, 28.IX.2006, fl., L.F.S. Magnago 1470 (MBML). Nova Venécia, 16.VII.2008, fl., A.M.A. Amorim 7503 (RB). Santa Teresa, 19.X.1999, fl., V. Demuner 137 (MBML). 


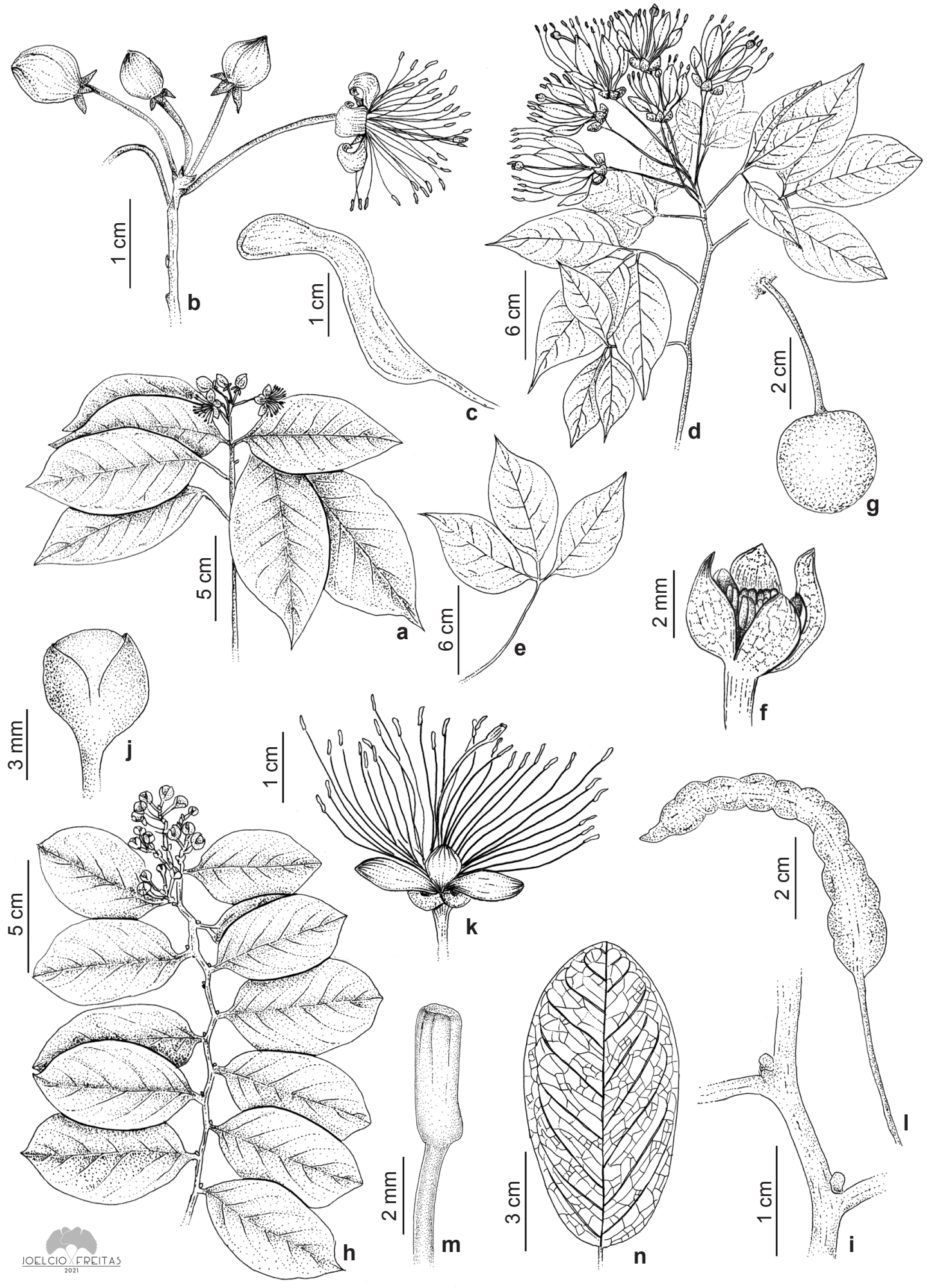

Figure 3 -a-c. Capparidastrum frondosum - a. habit; b. inflorescence with emphasis on flower at anthesis with reflexed sepals; c. fruit. d-g. Crateva tapia - d. habit; e. leaf 3-foliolate; f. flower buds; g. fruit. h-n. Cynophalla flexuosa - h. habit; i. branch with emphasis on nectaries on the leaf axil; j. flower buds; $k$. flower at anthesis; 1 . follicular capsule fruit. $\mathrm{m}$. gynophore and ovary differentiated; $\mathrm{n}$. leaf blade with reticulate tertiary veination. 
Vila Velha, 28.IX.1999, fl., C.N. Fraga 491 (MBML). Vitória, 12.X.1984, fl., S.S. Scolforo 303 (RB).

Additional specimens studied (Fruit): BRAZIL. RIO DE JANEIRO: Cabo Frio, 20.VI.1997, fr., A. Lobão et al. 277 (RB).

Popularly known as "guaxica", C. frondosum has a wide neotropical distribution, covering regions from Mexico to southern Brazil. In Brazil, the species occurs in the Amazon rainforest, Caatinga, and Atlantic Forest biomes. Along with its wide distribution, the species exhibits wide morphological variation. The specimens occurring in Espírito Santo (C.N. Fraga 491; S.S. Scolforo 303; L.F.S. Magnago 1470) require complementation with new collections to provide a better understanding of morphological traits.

2.1. Crateva tapia L., Species Plantarum 1: 444. 1753.

Fig. 3d-g

Tree or shrub 3-20 m tall. Leaves alternate spiral, 3-foliolate, petiole 72-165 mm long, cylindrical, glabrous; nectary on the leaf axil absent, petiole 9-13 mm long, cylindrical to slightly channeled, glabrous; blade 7.9-13.5 × 4.8-6.5 cm, glabrous on both sides, membranaceous, elliptical to ovate, apex acute to attenuated, base rounded; veins abaxially and adaxially impressed, 7-8 pairs, tertiary veins impressed and little reticulate on both sides. Inflorescences a raceme, terminal; Flowers asymmetrical, 30-60 per inflorescence, inflorescence axis 60-80 mm long; bracts not seen; pedicel 19-35 mm long, glabrous; floral bud not seen; 4 nectaries; calyx open at anthesis; sepals homomorphic, 5-6 × 3-4 mm, membranaceous, ovate, glabrous, green; petals 4 , unguiculate, claw 5-6 mm long, blade 14-17 × 5-7 mm, elliptical, margin entire, membranaceous, glabrous, white, erect at anthesis; stamens 16-17; filaments 28-48 $\mathrm{mm}$ long, glabrous, purple, 1 lines of insertion; anthers $3 \mathrm{~mm}$ long, basifixed, oblong; gynophore 21-42 mm long, glabrous, not fenestrated; stigma capitate, black when dry; ovary 2-2.2 mm long, glabrous, differentiated from the gynophore. Fruits globose amphisarca, indehiscent, yellow, 2.9-3.6 $\times 2.8-3.4 \mathrm{~cm}$; peduncle $42-45 \times 2 \mathrm{~mm}$; developed gynophore $40-43 \times 2-3 \mathrm{~mm}$.

Specimens studied: Cariacica, 28.III.2003, fr., A.G. Chisto et al. 218 (RB). Governador Lindemberg, 5.XI.2007, fl. and fr., V. Demuner et al. 4454 (MBML). Guarapari, 26.XI.1992, fl., V. de Souza 407 (CVRD). Itapemirim, 28.XII.2007, fr., A.M. Assis et al. 1232 (MBML). Linhares, 4.III.1993, fr., D.A. Folli 1818 (CVRD); 6.XII.2007, fl., D.A. Folli 5795 (CVRD); 20.XI.1972, fl. and fr., J. Spada 79 (RB); 24.X.2008, fl., L.Kollmann et al. 11279 (MBML); 23.I.2013, fr., $R$. Coelho et al. 282 (SAMES). Nova Venécia, 10.X.1996, fl., H.Q.B. Fernandes et al. 3191 (MBML); 13.I.2009, fr., P.H. Labiack et al. 5082 (RB). Presidente Kennedy, 1.XII.2013, fl., G.S. Siqueira 934 (CVRD, RB). Santa Teresa, 19.X.1999, fl. and fr., V. Demuner 125 (MBML); 10.II.2012, fr., J. Gurtler et al. 93 (MBML). São Mateus, 6.XI.2007, fl., C. Farney et al. 4825 (RB). Viana, 1.II.2016, fr., M. Ribeiro et al. 1226 (RB). Vila Velha, 6.XI.1983, fl., B. Weinberg 478 (MBML).

Popularly known as "pau-cebola", C. tapia is one of the most easily recognized species of Capparaceae in the field due to the presence of very marked lenticels on its branches, 3-foliolate leaves, and zygomorphic flowers. This species occurs from Central America to Argentina, being found in almost all of the Brazilian territory with the exception of the southern region, and in the Amazon rainforest, Caatinga, Cerrado, and Atlantic Forest biomes.

3.1. Cynophalla flexuosa (L.) J. Presl., O Přirozenosti rostlin, aneb rostlinar 2: 275. 1825.

Figs. 3h-n; 4b

Tree or shrub 2-10 $\mathrm{m}$ tall. Leaves alternate distichous, simple, petiole 5-10 mm long, canaliculate, glabrous; nectary on the leaf axil present; blade $6-12.5 \times 3.3-6.6 \mathrm{~cm}$, glabrous on both sides, coriaceous, elliptical to obovate, apex cuneate, rounded or obtuse, base obtuse, rounded, subcordate or cordate; veins adaxially and abaxially prominent, 8-11 pairs, tertiary veins abaxially prominent and adaxially prominent or impressed, densely reticulate. Inflorescences a raceme or panicle, terminal or axillary. Flowers symmetrical, 5-14(-24) per inflorescence, inflorescence axis 20-25 mm long; bracts $1 \mathrm{~mm}$ long, glabrous, chartaceous, deltoid; pedicel 10-15 mm long, glabrous; floral bud 10-13 × 9-11 mm; 4 nectaries, calyx open at anthesis; sepals heteromorphic; external sepals 5-7 × 6-8 mm, chartaceous, broadelliptical, glabrous, green; internal sepals $7 \times 4-10$ $\mathrm{mm}$, chartaceous, elliptical to wide-elliptical, glabrous, green; petals 4, 12-18 × 8-10 mm, wideelliptical, margin entire, membranaceous, glabrous, white, reflexed or non-reflexed at anthesis; stamens 100; filaments 14-19 mm long, glabrous, white, 4-5 lines of insertion; anthers 3-3.5 mm long, basifixed, oblong; gynophore, 15-25 mm long, glabrous, slightly fenestrated; stigma capitate, black when dry; ovary 4-5 mm long, glabrous, differentiated from the gynophore. Fruits follicular capsule, dehiscent, red, $5.7-13.9 \times 0.8-1.24 \mathrm{~cm}$; peduncle $10-17 \times 1.5-3$ $\mathrm{mm}$; developed gynophore $37-54 \times 1.1-2.3 \mathrm{~mm}$. 

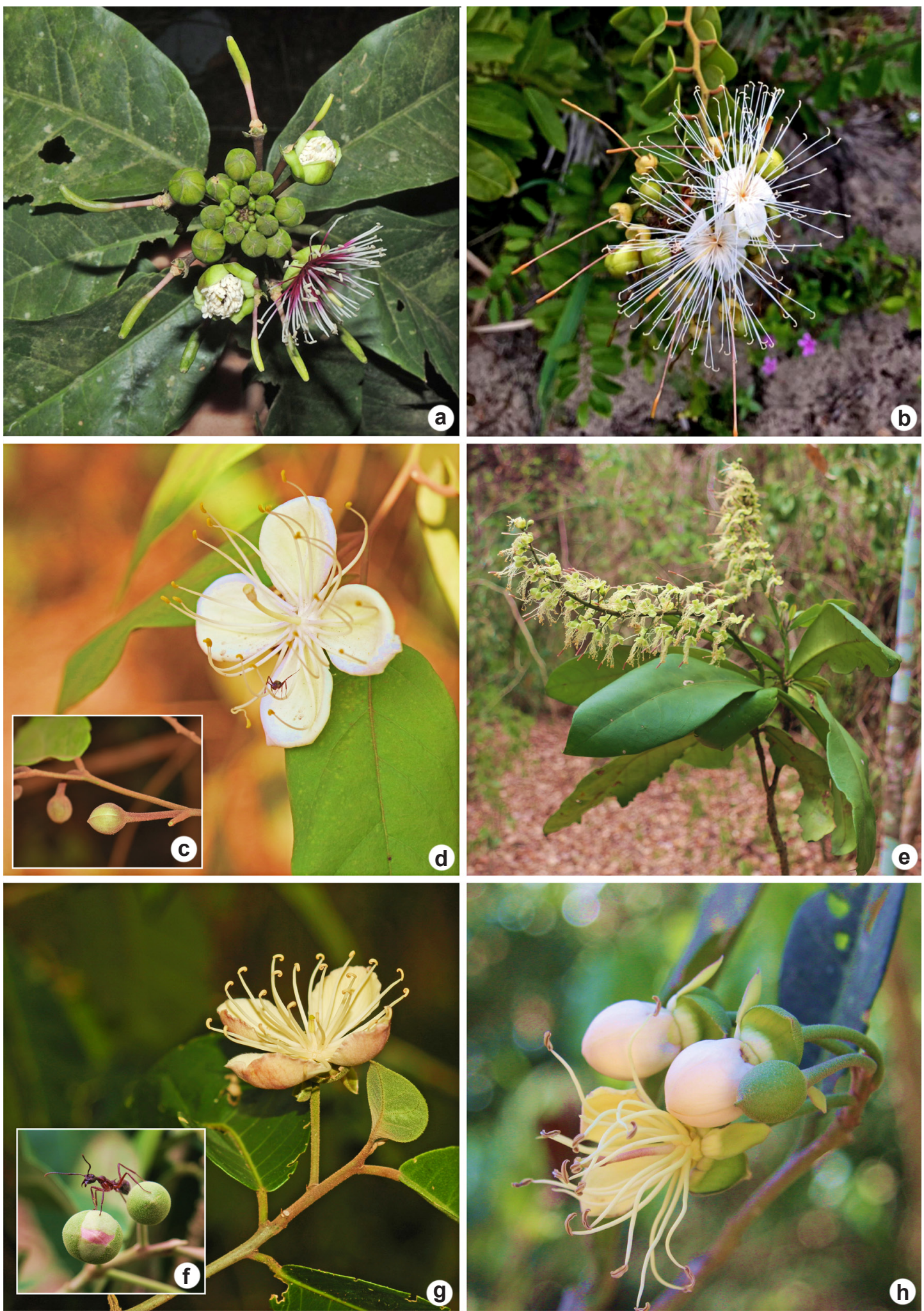

Figure 4 - a. Capparidastrum frondosum. b. Cynophalla flexuosa. c-d. Mesocapparis lineata. e. Monilicrapa brasiliana. f-g. Neocalyptrocalyx atlanticum. h. Neocalyptrocalyx nectarius. Photos: a. Thiago Fernandes; b. Cássio Augusto Patrocínio Toledo; c-h. Jaquelini Luber. 
Specimens studied: Conceição da Barra, 9.I.1992, fl., D.A. Folli 1551 (CVRD); 13.VI.2012, fl., L.F.T. Menezes 2003 (SAMES); 19.VIII.1991, fr., V. de Souza 131 (CVRD); 20.V.1999, fl., G. Hatschbach 69185 (MBML); 8.XI.1990, fl., E.N. Moraes 51 (CVRD); 10.VI.1992, fr., O.J. Pereira 3490 (VIES); 20.II.2000, fl., A.M. Assis 795 (VIES). Itapemirim, 28.XII.2007, fl. and fr., A.M. Assis 1265 (MBML). Linhares, 1.II.1999, fl., V.F. Mansano 41 (CVRD); 14.VII.2010, fr., A.O. Giaretta 803 (SAMES); 1.VI.1993, fr., D.A. Folli 1884 (CVRD); 11.IV.2006, fl., J. Paula-Souza 5717 (RB); 10.III.1994, fl. and fr., D.A. Folli 2247 (RB); 15.III.2007, fl., L.F.T. Menezes 1660 (SAMES). Marataízes, 13.V.1991, fl. and fr., V. de Souza 82 (CVRD). Piúma, 15.V.2010, fr., F.L. Santos 191 (MBML); IX.2002, fl., H. Pinheiro 21 (VIES); 24.X.2002, fr., H. Pinheiro 42 (VIES). Presidente Kennedy, I.2018, fl. and fr., J. Luber 230 (CAP); 1.XII.2013, fl., G.S. Siqueira 932 (CVRD); 27.IV.1997, fr., O.J. Pereira 5857 (VIES); 13.X.2011, fl., R.T. Valadares 1004 (VIES); 27.IV.1997, fl., O.J. Pereira 5875 (VIES); 26.VIII.1996, fr., J.M.L. Gomes 2153 (VIES); 27.IX.2009, fr., M. Silva 145 (RB); 17.X.2008, fl., A.C.S. Cavalcante 270 (RB); 25.IX.2016, fr., K.S. Valdemarin 81 (RB). São Mateus, 20.III.2008, fl. and fr., R.F.A. Martins 199 (SAMES); 1.IX.2007, fl., M.B. Faria 64 (SAMES); 7.XI.2007, fl., C. Farney 4834 (RB). Vila Velha, 7.IV.2012, fl., L.A. Silva 142 (VIES); 28.XI.1996, fl., O.J. Pereira 5691 (VIES); 6.IV.1993, fr., V. de Souza 479 (CVRD); 6.VII.1996, fr., J.M.L. Gomes 2120 (VIES). Vitória, 3.I.1985, fl., N.M. Heleodoro 274 (RB); 2004, fr., G.N. Martins 206(VIES); 21.I.1998, fl., A.M. Assis 360 (VIES).

Cynophalla flexuosa, popularly known as "feijão-da-praia", is the species that has the greatest morphological variation in the genus. It has a wide distribution, occurring from the United States to the south of Brazil, and its morphological variation is sometimes confused and little understood. Recent studies have shown which characters help to better define species and have led to the description of new species for the genus, such as those presented by Cornejo et al. (2020) and the present work. In Brazil, it occurs in the Amazon rainforest, Caatinga, Cerrado, Atlantic Forest, Pantanal biomes. In state of Espírito Santo, C. flexuosa has wide distribution in coastal plains.

3.2. Cynophalla grandiflora Luber sp. nov. Type: BRAZIL. ESPÍRITO SANTO: Linhares, Flona de Goytacazes, Mata de tabuleiro/Mata aluvial, $21 \mathrm{~m}$ altitude, 20.XI.2017, fl., D.A. Folli 7593 (Holotype: CVRD! [CVRD15806] Isotype: RB! [RB767636]).

Fig. 5

Cynophalla grandiflora Luber is a new species occurring in the "tabuleiros costeiros" of the Atlantic Forest. The species resembles Cynophalla flexuosa, but differs from it mainly by the membranaceous leaves and the impressed and slightly reticulate tertiary veins (versus chartaceous leaves with strongly prominent and more reticulate tertiary veins in C.flexuosa), the size of the flowers, with external sepals measuring 8-10 × 7-10 mm (versus 5-7 × 6-8 $\mathrm{mm}$ in $C$. flexuosa), internal sepals $14 \times 12-13 \mathrm{~mm}$ (versus $7 \times 4-10 \mathrm{~mm}$ in $C$. flexuosa), petals 20-30 × 18-22 mm (versus $12-18$ $\times 8-10 \mathrm{~mm}$ in $C$. flexuosa) and by the ovary that is not differentiated from the gynophore (versus ovary strongly differentiated from the gynophore in C. flexuosa).

Tree $6 \mathrm{~m}$ tall. Leaves alternate distichous, simple, petiole 5-5.5 $\mathrm{mm}$ long, canaliculate, glabrous; nectary on the leaf axil present; blade 9-13.9 $\times$ 4.2-5.5 cm, glabrous on both sides, membranaceous, elliptical, apex attenuate, base cuneate; veins abaxially prominent and adaxially impressed, 9-10 pairs, tertiary veins impressed and slightly reticulate on both sides. Inflorescences a raceme, terminal. Flowers symmetrical, 4-7 per inflorescence, inflorescence axis 7-22 mm long; bracts $1 \mathrm{~mm}$ long, glabrous, chartaceous, deltoid; pedicel 14-15 mm long, glabrous; floral buds $21 \times$ 19 mm; 4 nectaries; calyx open at anthesis; sepals heteromorphic; external sepals 8-10 × 7-10 mm, chartaceous, broad-elliptical, glabrous, green; internal sepals $14 \times 12-13 \mathrm{~mm}$, chartaceous, broad-elliptical, glabrous, green; petals 4, 20-30 $\times$ 18-22 mm, wide-elliptical, margin entire, membranaceous, glabrous, white, not reflexed at anthesis; filaments $66 \mathrm{~mm}$ long, glabrous, white, 4 lines of insertion; stamens ca. 120; anthers 3.5 mm long, basifixed, oblong; gynophore, 37-50 mm long, glabrous, slightly fenestrated; stigma capitate, black when dry; ovary $8 \mathrm{~mm}$ long, glabrous, not differentiated from the gynophore. Fruits not seen.

The epithet refers to the size of the flowers which is larger than that of the flowers of closely related species.

Cynophalla grandiflora, a new species for science, was previously included within the circumscription of C. flexuosa sensu lato, that among the species of the genus, it is the one that most resembles morphologically with $C$. grandiflora. However, its larger flowers and more delicate leaves have drawn attention to more detailed studies. This species has a smaller reticulation of the tertiary veins (Fig. 5b), differing from $C$. flexuosa, which has a more reticulate tertiary veination (Fig. 3i). This characteristic is 


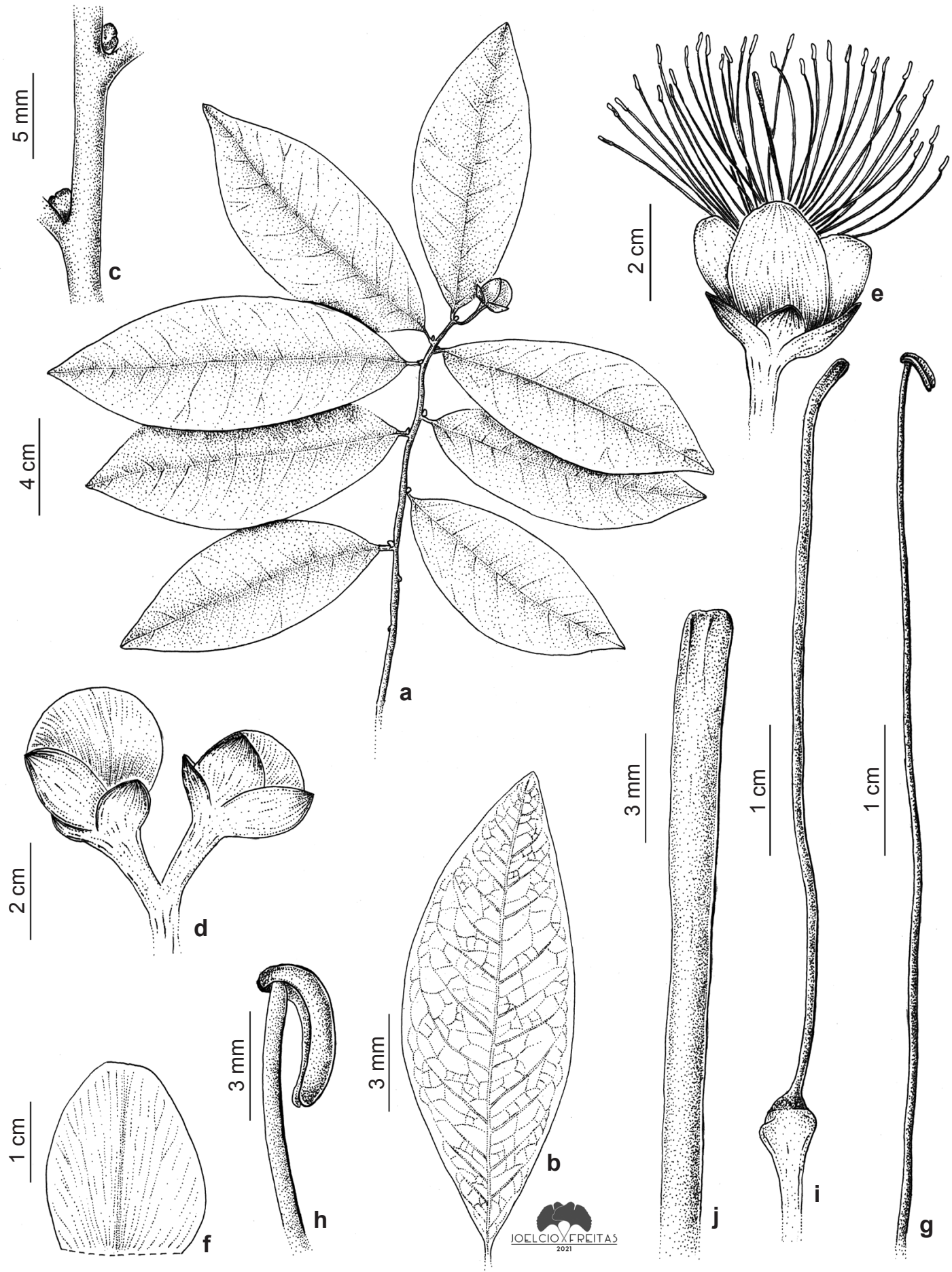

Figure 5 - a-j. Cynophalla grandiflora - a. habit; b. leaf blade with less reticulate tertiary veins; c. nectary on the leaf axil; d. flowers buds; e. flower at anthesis; f. petal; g. filament; h. anther in detail; i. gynecium; j. gynophore and ovary not differentiated. 
important for the identification of the species, particularly when sterile; the nectaries in the leaf axil (Figs. 3j; 5c) help to identify the genus Cynophalla, and the tertiary veins are key to identify the species. So far this species is restricted to one collection, being then endemic to "tabuleiro costeiro" forest in Espírito Santo. Its classification as to the degree of threat cannot be determined due to lack of data.

4.1. Mesocapparis lineata (Dombey ex Pers.) Cornejo \& Iltis, Harvard Papers in Botany 13(1): 115-116, f. 4. 2008.

Figs. 4c-d; 6a-g

Herbaceous or woody liana. Leaves alternate distichous, simple, petiole 5-12 $\mathrm{mm}$ long, cylindrical, tomentose with stellate trichomes; nectary on the leaf axil absent; blade 5.3-8.6 $\times$ $2.7-4.1 \mathrm{~cm}$, tomentose on the abaxial face and pubescent on the adaxial face, chartaceous, ovate, apex attenuate to cuneate, base rounded to cuneate; veins abaxially prominent and adaxially grooved, 5-7 pairs, tertiary veins impressed on both sides, barely reticulate, and barely visible. Inflorescences solitary, axillary. Flowers symmetrical; bracts absent; pedicel 9-19 $\mathrm{mm}$ long, tomentose; floral buds 7-10 × 6-9 mm; 4 nectaries; calyx open at anthesis; sepals 4, homomorphic, 6.3-13 × 5-8 $\mathrm{mm}$, membranaceous, oblong, glabrous, green; petals $4,14-16 \times 10-15 \mathrm{~mm}$, obovate, slightly bulging, membranaceous, glabrous, white, light yellow, not reflexed at anthesis; stamens 20-24; filaments, 26-39 mm long, glabrous, white, 2 lines of insertion; anthers $2-2.6 \mathrm{~mm}$, basifixed, triangular; gynophore, 17-26 mm long, glabrous, fenestrated; stigma capitate, vinaceous when dry; ovary 3-3.8 mm long, tomentose, differentiated from the gynophore. Fruits globose amphisarca, indehiscent, green, $5.5-8.3 \times 3.5-4.1 \mathrm{~cm}$; peduncle ca. $30 \times 2 \mathrm{~mm}$; developed gynophore $25-26 \times$ $1.5-2 \mathrm{~mm}$.

Specimens studied: Barra de São Francisco, 21.XI.2000, f1., L. Kollmann 3271 (MBML). Linhares, 16.XI.2000, fl., D.A. Folli 3742 (CVRD); 2.XII.2013, fl., D.A. Folli 2081 (RB); 10.I.2008, fl., D.A. Folli 5843 (RB). São Mateus, 10.XI.1993, fl., G. Hatschbach 60073 (INPA). Vitória, 8.XI.1959, fl., J.G. Kuhhmann 6402 (RB).

Additional specimens studied (Fruit): BRAZIL. RIO DE JANEIRO: São Gonçalo, 12.VII.1997, fr., R.N. Damasceno [RB00065331] (RB); 1992/1993, fr., S.M. Schneider [RB00066440] (RB); 24.III.1987, fr., C. Farney et al. 1368 (RB).

Mesocapparis lineata, popularly known as "erveira", belongs to an endemic genus of Brazil occurring in the Amazon rainforest, Caatinga and Atlantic Forest biomes. It differs from other species in the field for its lianescent habit, being unique among the species treated here.

5.1. Monilicarpa brasiliana (Banks ex DC.) Cornejo \& Iltis, Journal of the Botanical Research Institute of Texas 2(1): 71. 2008. Figs. 4e; 6h-i

Tree or shrub 2.5-7 $\mathrm{m}$ tall. Leaves opposite, verticilated, simple, petiole $2-7 \mathrm{~mm}$ long, cylindrical, glabrous; nectary on the leaf axil absent; blade 16.4-21 × 4.6-6.6 cm, glabrous on both sides, chartaceous, elliptical, apex attenuate, acute, cuspidate or acuminate, base cordate, cuneate, attenuate or obtuse; veins abaxially impressed or prominent and adaxially impressed, 9-14 pairs, tertiary veins not visible. Inflorescences a raceme, terminal. Flowers symmetrical, 26-76 per inflorescence, inflorescence axis 8-20 cm long; bracts $2-3 \mathrm{~mm}$ long, pubescent, membranous, narrow-elliptical; pedicel $20-30 \mathrm{~mm}$ long, glabrous or pubescent; floral buds 4.4-6.5 × 3-4 mm; nectaries absent; calyx open at anthesis; sepals 4, homomorphic, 2-3 × $1 \mathrm{~mm}$, membranaceous, deltoid, glabrous, rarely pubescent, green; petals $4,5-9 \times 2.2-5.3 \mathrm{~mm}$, oblong to obovate, margin entire, membranaceous, glabrous, white, in green and yellow hues, not reflexed at anthesis; stamens 14-23; filaments, 10-20 mm long, glabrous, white, 2 lines of insertion; anthers 1.4-2 mm long, basifixed, linear; gynophore 10-11 mm long, glabrous, not fenestrated; stigma capitate, brown; ovary $2.7-3.5 \mathrm{~mm}$ long, glabrous, differentiated from the gynophore. Fruits moniliform capsule, dehiscent, purple, $12-27 \times 0.7-0.85 \mathrm{~cm}$; peduncle 16-23 $\times 1.2-1.4 \mathrm{~mm}$; developed gynophore $25-30$ $\times 2-3 \mathrm{~mm}$.

Specimens studied: Linhares, 10.XI.1992, fl., D.A. Folli 1722 (RB); 23.IX.1991, fr., D.A. Folli 1425 (RB); 6.XI.1972, fl., J. Spada 52 (RB); 23.X.2010, fl., T.B. Flores 908 (RB); 29.X.2004, fl., G.S. Siqueira 130 (RB); 11.XI.1991, fl., D.A. Folli 1485 (RB). Pinheiros, 4.X.2007, fl., D.A. Folli 5727 (CVRD). Rio Bananal, 6.XI.2007, fl., V. Demuner et al. 4463 (MBML). Sooretama, 19.IV.2011, fr., J. Meirelles 605 (RB); X.2017, fl., (RB 759852); X.2017, fl. and fr., (RB 759422).

Monilicarpa brasiliana, popularly known as "estape", with distribution restricted to Brazil, occurring in the Atlantic Forest and Pantanal biomes. This species is easily differentiated from the other species by lacking floral and extrafloral nectaries and bearing moniliform capsule fruits. 

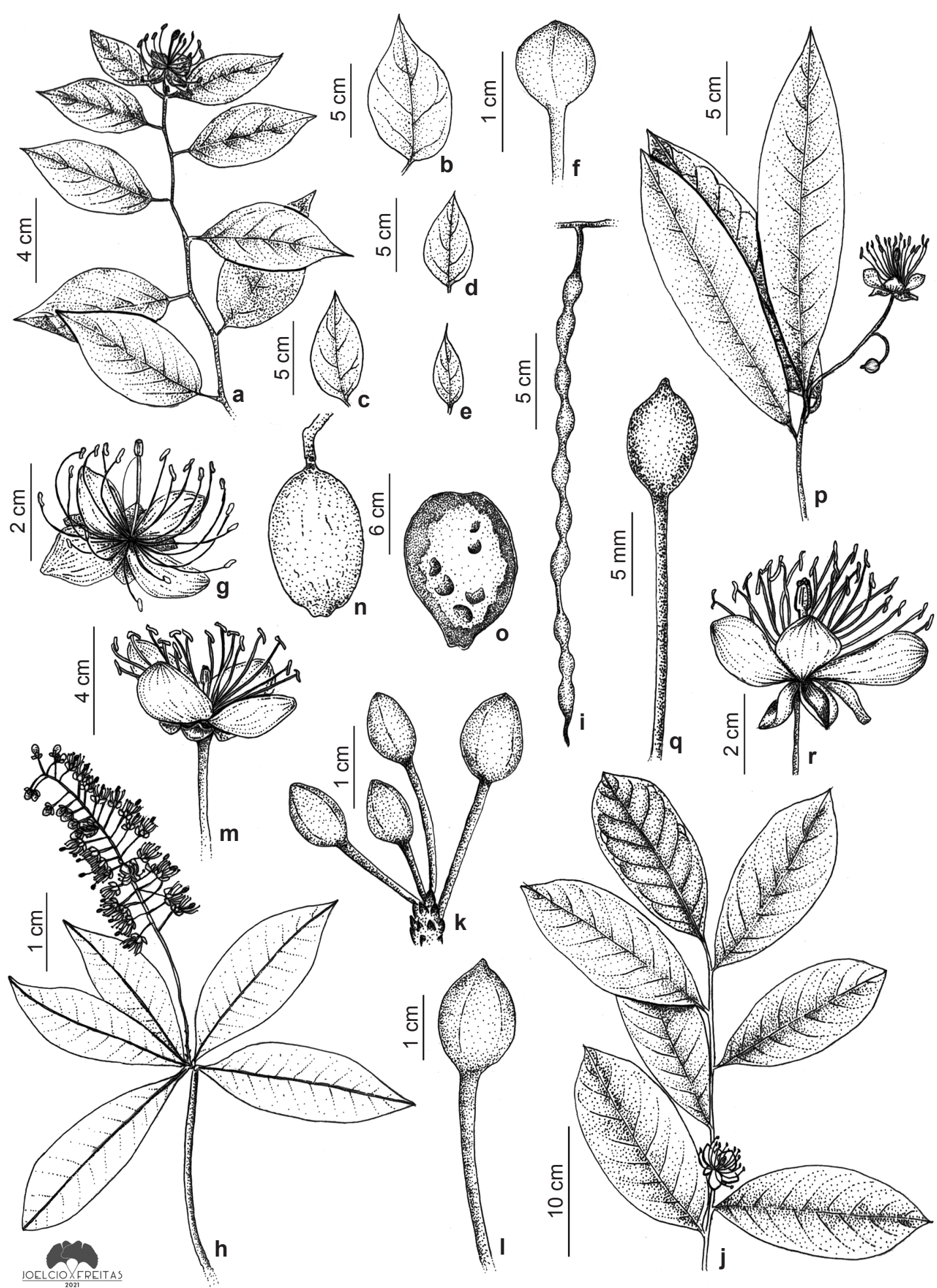
6.1. Neocalyptrocalyx atlanticum Luber \& Cornejo, Systematic Botany 3:XX. 2021.

Figs. 4f-g; 6j-o

Tree or shrub 5-7 m tall. Leaves alternate distichous, simple, petiole $9.2-10 \mathrm{~mm}$ long, cylindrical to slightly canaliculate, pubescent with stellate trichomes; nectary on the leaf axil absent; blade 13.3-19.2 × 4.9-6 cm, pubescent on the abaxial face and glabrous on the adaxial face, coriaceous, elliptical, apex attenuate, base rounded; veins abaxially prominent and adaxially impressed, 11-13 pairs, tertiary veins impressed and little reticulate on both sides. Inflorescences solitary or a raceme, terminal or axillary. Flowers symmetrical, 2-4 per inflorescence, inflorescence axis 16-22 mm long; bracts $2 \mathrm{~mm}$ long, glabrous, chartaceous, narrow-triangular; pedicel 23-44 $\mathrm{mm}$ long, glabrous or pubescent; floral buds $12-20 \times 15 \mathrm{~mm}$, apex thinly apiculate to broadly obtuse; 4 nectaries; calyx fused at anthesis; sepals heteromorphic; external sepals 9-12 $\times$ 8-9 $\mathrm{mm}$, chartaceous, obovate to broad elliptical, pubescent, green; internal sepals 10-11 $\times 3 \mathrm{~mm}$, membranaceous, oblanceolate, pubescent, cream; petals $4,15-21 \times 7-14 \mathrm{~mm}$, obovate, slightly bulging, membranaceous, pubescent, light pink, not reflexed at anthesis; stamens 15-16; filaments 10-22 $\mathrm{mm}$ long, pubescent at the base and glabrous at the apex, white, 3 lines of insertion; anthers 3 $\mathrm{mm}$ long, basifixed, reiniform; gynophore, $3.5 \mathrm{~mm}$ long, glabrous, slightly fenestrated; stigma capitate, dark brown to brown when dry; ovary $3 \mathrm{~mm}$ long, pubescent, differentiated from the gynophore. Fruits elliptical amphisarca, indehiscent, green, $6.7-8 \times 4.5-4.1 \mathrm{~cm}$; peduncle $10-11 \times 4.3-5.4 \mathrm{~mm}$; developed gynophore 10-19 × 5-8 mm.

Specimens studied: Itapemirim, fazenda do ouvidor, 14.III.2008, fr., A.M. Assis et al. 1420 (MBML); 24.I.2008, fr., A.M. Assis et al. 1305 (MBML); 28.XII.2007, fr., A.M. Assis et al. 1244 (MBML). Additional specimens studied (Flower buds and Flowers): BRAZIL. BAHIA: Ipiaú, 26.X.1970, f1., T.S. Santos 1192 (CEPEC). PERNAMBUCO: Vicência, 12.XI.1960, fl., S. Tavares 545 (US). Timbaúba, 23.X.1958, fl., Andrade-Lima 3281 (MAC).

Neocalyptrocalyx atlanticum, popularly known as "araticum-da-mata", "araticum-icó", "cabeça-de-girú", "cacau-do-mato", "coité-domato", and "girú-limão", was recently described for the Atlantic Forest and is endemic to this biome. Espírito Santo is the southern limit of distribution of the species, which goes up to Pernambuco, which is the northern limit. Neocalyptrocalyx atlanticum can be confused with $N$. nectarius, however its light pink flowers and the rounded apex of the buds differentiate them.

6.2. Neocalyptrocalyx nectarius (Vell.) Hutch., The Genera of Flowering Plants 2: 308. 1967.

Figs. 4h; 6p-r

Tree $2-5 \mathrm{~m}$ tall. Leaves alternate spiral, simple, petiole 9-14 $\mathrm{mm}$ long, cylindrical, pubescent with stellate trichomes; nectary on the leaf axil absent; blade 17.9-4.5 × 4.8-7.6 cm, pubescent on both sides, coriaceous, lanceolate to elliptic-lanceolate, apex sharply acuminate, base cuneate to subcordate; veins abaxially prominent and adaxially prominent or impressed, 12-17 pairs, tertiary veins impressed and little reticulate on both sides. Inflorescences solitary or a raceme, terminal or axillary. Flowers symmetrical, 3-9 per inflorescence, inflorescence axis 39-41 $\mathrm{mm}$ long; bracts $2.8-4.5 \mathrm{~mm}$ long, pubescent, chartaceous, narrow-triangular; pedicel 25-50 $\mathrm{mm}$ long, pubescent; floral buds 9-12 × 7-9 $\mathrm{mm}$, apex acuminate; 4 nectaries; calyx fused at anthesis; sepals heteromorphic; external sepals $15-17 \times 13-15 \mathrm{~mm}$, chartaceous, ovate to broad elliptical, pubescent, green; internal sepals 13-20 $\times 6.7-7.8 \mathrm{~mm}$, membranaceous, elliptical to narrow-elliptical, pubescent, cream; petals 4, $25-35 \times 17-25 \mathrm{~mm}$, obovate, slightly bulging, membranaceous, glabrous, white, not reflexed at anthesis; stamens 14-20; filaments 23-33 $\mathrm{mm}$ long, pubescent at the base, white, 2 lines of insertion; anthers 3.7-4 mm long, basifixed, reiniform; gynophore 11-19 mm long, pubescent, slightly twisted; stigma capitate, brown when dry; ovary 5.3-6.5 $\mathrm{mm}$ long, pubescent, differentiated from the gynophore. Fruits elliptical amphisarca, indehiscent, green, $9.2 \times 5.6 \mathrm{~cm}$; peduncle $55 \times 5.4$ $\mathrm{mm}$; developed gynophore $20 \times 7.6 \mathrm{~mm}$.

Specimens studied: Anchieta, 1.XII.2006, fl., A.M. Assis 1188 (MBML). Linhares, 28.I.2009, fr., G.S. Siqueira 460 (CVRD); 28.XII.2006, fl., D.A. Folli 5412 (CVRD); 11.XII.2006, fr., D.A. Folli 5415 (CVRD); 6.XII.2007, fl., D.A. Folli 5805 (CVRD); 12.XI.2014, fl., G.S. Siqueira 1013 (CVRD); 31.X.2001, fl., D.A. Folli 4103 (CVRD); 27.X.2015, fl., G.S. Siqueira 1100 (RB); 4.XI.2019, fl., J. Luber et al. 461 (RB); 4.XI.2019, fl., J. Luber et al. 462 (RB); 4.XI.2019, fl., J. Luber et al. 463 (RB); 31.X.2001, fl., D.A. Folli 4103 (CVRD).

Neocalyptrocaly nectarius, popularly known as "mirasul", "estape-branco", and "coração-deboi", is an endemic species of the Atlantic Forest, with distribution restricted to Espírito Santo and the north of the state Rio de Janeiro. This species can be easily confused with Neocalyptrocalyx 
atlanticum, however it is distinguished from it by the completely white flowers and the strongly attached apex of the bud.

\section{Acknowledgments}

J. Luber was partially supported by the Coordenação de Aperfeiçoamento de Pessoal de Nível Superior - Brasil (CAPES) - Finance Code $n^{\circ} 88882.447055 / 2019-01$; and thanks the Conselho Nacional de Desenvolvimento Científico e Tecnológico ( $\mathrm{CNPq}$ ), for provision of a doctoral fellowship; and the National Geographic Society for awarding a grant for the work (Early Career Grant). T.T. Carrijo and V.F. Mansano thank the Conselho Nacional de Desenvolvimento Científico e Tecnológico - CNPq, for the research grant (Bolsa de Produtividade em Pesquisa). The authors thank the curators and keepers of the visited herbaria, for allowing the access to their collections; Geovane Siqueira, for providing detailed photos of fundamental materials for the development of the work; and the anonymous owners of properties who allowed visits for collection of material. T.T. Carrijo also thank the Fundação de Amparo à Pesquisa e Inovação do Espírito Santo (FAPES) for the research grant "Taxa de Pesquisa".

\section{References}

Cardinal-McTeague WM, Sytsma KJ \& Hall JC (2016) Biogeography and diversification of Brassicales: a 103 million year tale. Molecular Phylogenetics and Evolution 99: 204-224.

Carvalho LAF (1959) Capparidaceae do Rio de Janeiro. Rodriguésia 33: 329-337.

Cornejo X (2020) Acanthocapparis (Capparaceae): a new genus from Mesoamerica. Harvard Papers in Botany 25: 43-46.

Cornejo X \& Iltis HH (2008a) Two new genera of Capparaceae: Sarcotoxicum and Mesocapparis stat. nov., and the reinstatement of Neocalyptrocalyx. Harvard Papers in Botany 13: 109-113.

Cornejo X \& Iltis HH (2008b) Anisocapparis y Monilicarpa dos nuevos géneros de Capparaceae de América del Sur. Journal of the Botanical Research Institute of Texas 2: 61-74.

Cornejo X \& Iltis HH (2008c) Neocalyptrocalyx morii (Capparaceae), a new species from central French Guiana. Journal of the Botanical Research Institute of Texas 2: 807-810.

Cornejo X \& Iltis HH (2009a) Hispaniolanthus: a new genus of Capparaceae endemic to Hispaniola. Harvard Papers in Botany 14: 9-14.

Cornejo X \& Iltis HH (2009b) The reinstatement of Beautempsia (Capparaceae) and a key to the genera of Neotropical Capparaceae with variously stellate or peltate indumenta. Journal of the Botanical Research Institute of Texas 3: 683-689.

Cornejo X \& Iltis HH (2010) Studies in the Capparaceae XXIX: synopsis of Quadrella, a Mesoamerican and West Indies genus. Journal of the Botanical Research Institute of Texas 4: 117-132.

Cornejo X \& Iltis HH (2012) Capparaceae. Available at $<$ http://floradejalisco.cucba.udg.mx/FJAC 25 capparaceae.pdf $>$. Access on 20 September 2017.

Cornejo X, Iltis HH \& Céron CE (2014) Capparidastrum tafallanum (Capparaceae), a new species from the Northwestern Andean Slopes of Ecuador. Harvard Papers in Botany 19: 189-191.

Cornejo X \& Vargas W (2020) Capparidastrum alboannulatum: a new species and new records of Capparaceae from Colombia. Harvard Papers in Botany 25: 39-41.

Cornejo X, Luber J \& Iltis HH (2020) Notes on the genus Cynophalla (Capparaceae) and the description of $C$. amazonica a new species from Bolivia and Brazil. Phytotaxa 461: 204-212.

Costa e Silva MB (1995) Estudos taxonômicos sobre o gênero Capparis L. (Capparaceae Juss.) em Pernambuco. Dissertação de Mestrado. Universidade Federal Rural de Pernambuco, Recife. $163 \mathrm{p}$.

CRIA (2015) INCT - Herbario virtual das plantas e fungos. Available at <http://inct.splink.org.br/ index $>$. Access on 30 July 2015.

Cronquist A (1981) An integrated system of classification of flowering plants. Columbia University Press, New York.

Endress PK (1992) Evolution and floral diversity: the phylogenetic surroundings of Arabidopsis and Antirrhinum. International Journal of Plant Sciences 153: S106-S122.

Global Plants - JSTOR (2020) Available at $<$ https:// plants.jstor.org/>. Access on 18 November 2020.

Gonçalves EG \& Lorenzi H (2007) Morfologia vegetal: organografia e dicionário ilustrado de morfologia das plantas vasculares. Editora Instituto Plantarum de Estudos da Flora Ltda., Nova Odessa. 448p.

Heywood VH (1993) Capparis L. In: Tutin TG, Burges NA, Chater AO, Edmondson JR, Heywood VH, Moore DM, Valentine DH, Walters SM \& Webb DA (eds.) Flora Europaea, 1. 2nd ed. Cambridge University Press, Cambridge.

Iltis HH \& Cornejo X (2007) Studies in the Capparaceae XXX: Capparicordis, a new genus from the neotropics. Brittonia 59: 245-254.

IPEMA - Instituto de Pesquisas da Mata Atlântica (2005) Conservação da Mata Atlântica no Espírito Santo: cobertura florestal e unidades de conservação. IPEMA, Vitória. 142p.

Mabberley DJ (1997) The plant-book: a portable dictionary of the vascular plants. Cambridge University Press, Cambridge. 
Mercado-Gómez JD \& Morales-Puentes ME (2020) A new species of Capparidastrum (Capparaceae Juss.) from the Cauca inter Andean valley of Colombia. Phytotaxa 439: 276-286.

Reflora - Herbário Virtual (2015) Avaiable at <http:// reflora.jbrj.gov.br/reflora/herbarioVirtual/>.Access on 18 November 2020.

Soares Neto RL \& Luber J (2020) Capparaceae in BFG - The Brazil Flora Group (2018) Brazilian Flora 2020: innovation and collaboration to meet Target 1 of the Global Strategy for Plant Conservation (GSPC). Rodriguésia 69: 1513-1527.
Soares Neto RL, Magalhães FAL, Silva FRS, Moro MF, Costa-e-Silva MB \& Loiola MIB (2014) Flora do Ceará, Brasil: Capparaceae. Rodriguésia 65: 671-684.

Soares Neto RL \& Jardim JG (2015) Capparaceae no Rio Grande do Norte, Brasil. Rodriguésia 66: 847-857.

Thiers B [continuously updated] Index Herbariorum: a global directory of public herbaria and associated staff. New York Botanical Garden's Virtual Herbarium. Available at $<$ http://sweetgum.nybg.org/ science/ih/>. Access on 24 August 2018. 